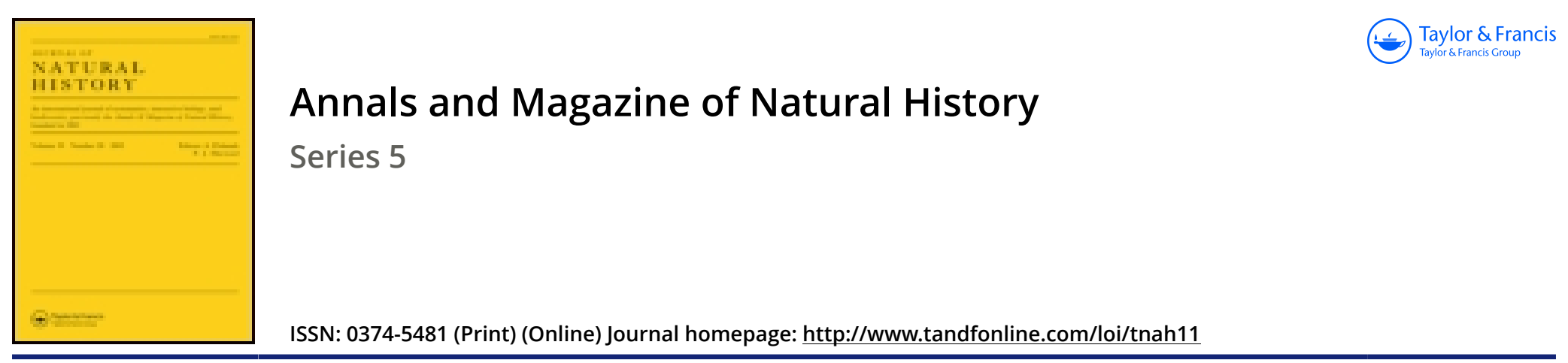

\title{
On the organization of the Crinoidea
}

\section{M.E. Perrier}

To cite this article: M.E. Perrier (1883) On the organization of the Crinoidea, Annals and Magazine of Natural History, 12:71, 358-360, DOI: 10.1080/00222938309459644

To link to this article: http://dx.doi.org/10.1080/00222938309459644

\section{曲 Published online: 09 Oct 2009.}

Submit your article to this journal ๘

Џ Article views: 4

Q View related articles $\sqsubset$ 
could not see the ducks, although the water was covered with them.

With the assistance of the coloured woman I got home, when I found my daughter similarly affected and unable to walk. Neither Mrs. Simms (the visitor) nor my cook were affected, which makes me know it was the oysters. The sickness and loss of vision gradually left us after drinking a cup of strong coffee. I am confident the death of the fish is caused by the discharge of poisonous gases from the bottom of the sea.

Mr. Williams, of Point Pinellas, thinks the mortality is "caused by a black scum on the water resembling soot," and Mr. Spencer, of the Tampa Tribune, says that "the water where the fish are dying looks black and slimy ;" and he ascribes this to the fall of an unusual amount of rain, the water of which, "becoming impregnated with the poison of decaying vegetation, is poured into the bay in unusual quantities and poisons the fish." Both these gentlemen allude to the unwholesomeness of the oysters; and the latter says, "the oyster-saloons here [Tampa] were obliged to close, as the oysters came near killing sereral people." According to MM. Forgarty and Whittaker, "the poisoned water runs in streaks," so that, of three smacks fishing in company, "two lost all their fish, while one lost none, the vessels being only a few hundred jards spart."-Proc. U.S. Nat. Mus., Sept. 1883, pp. 105, 107.

\section{On the Organization of the Crinoidea. \\ By M. E. Perruer.}

In the course of investigations which already date from several years ago, I was led to results with regard to the organization of the arms of the Comatulæ differing considerably from those which were announced by William Carpenter, and which have been since observed and variously interpreted by Herbert Carpenter, Greef, Tauber, Ludwig, and some other observers. In consequence of the peculiar facilities for study which they presented I had made my investigations principally upon very young individuals, or upon arms in process of regeneration; it was, on the contrary, upon adult individuals, and often in full prodnction, that the researches of the anatomists just cited were made. Hence it was probable that the divergences which existed between my original results and theirs might be due to the fact that the organization of the arms of Comatulæ undergoes important modifications with age. On the other hand, there are also serious divergences between the conclusions at which the various observers have arrived; and the publications of Lndwig have recently diffused ideas with respect to the Echinoderms which require to be rectified upon many points, ideas which we believe we have demonstrated to be incorrect with regard to the circulatory apparatus of the Urchins and Starfishes, and which would render any homology very difficult to establish in the group Echinodermata, if we accepted them for the Crinoids. This is 
what has led us to resume the study of the development and organization of the Comatulæ from the moment when the larva attaches itself up to the adult state. Being compelled for the present to interrupt these inrestigations during my royage on board the ' Talisman,' I beg the Academy's permission to communicate to it the principal results at which I think I have arrived.

Ludwig has described, in the Comatulæ, a complicated circulatory apparatus, the centre of which is a peculiar organ, sometimes called the heart, sometimes the dorsal organ, and which is a vascular plexus corresponding to the supposed hecurts of the Starfishes, Sea-Urchins, and Ophiuri. M. Jourdain was one of the first to express doubts as to the nature of the organ regarded as a heart in the Starfishes; I have demonstrated that in the Sea-Urehins and Starfishes this organ had a glandular structure-a result which has been confirmed by recent researches upon the Ophiuri and the Sea-Urchins. The dorsal organ of the Crinoids has the same structure as the supposed heart of the other Echinodermata; like this it must be designated by the name of the ovoid gland. The vessels which appear to start from it are nothing but ramifications of the gland, usually terminating in dilatations having the aspect of cæca. These ramifications run in the midst of innumerable trabeculæ of conjunctive tissue of the general cavity, which may themselves sometimes take on the appearance of vessels. In the Comatulæ, in the Pentacrinoid and in the Cystidean phase the ovoid gland already exists; it is a solid fusiform body, passing from the oral ring to the peduncle, of which it continues the axial cord. This body emits no ramification; there can therefore, at this moment, be no question of a vascular apparatus. In the adult Comatula the ovoid body is implanted upon one of the horizontal floors of the chambered organ.

The name given to this singular-looking organ shows that we know nothing of its physiological function. Nevertheless this function must be very important, for the chambered organ, of which scarcely the rudiments exist during the Cystidean phases, becomes developed in proportion as the Comatula acquires arms and cirri, and continues in connexion with all these parts by the intermediation of fibro-cellular cords which oceupy the axis of the calcareous part of the cirri and the arms. The determination of the nature of these cords may seem to determine the nature of the chambered organ itself. William and Herbert Carpenter see the nervous system in these cords; Ludwig simply designates them as fibrous cords, and with him the nervous system is only a simple modification of the epithelium of the ambulacral groove.

I have beon able to demonstrate not only that the fibro-cellular cords in question emit ramifieations which have all the appearance of true nerves, as seen by W. and H. Carpenter, but also that, wherever muscles exist, these muscles are clearly in connexion with ramifications of the fibrous cord. These ramifications divide into a great number of threads ; their last branches terminate at stellate cells, each of which is produced into a muscular fibre. Ramifications of this kind are likewise connected with the fibres which 
are contained by the ambulacral tentacles, and a great number of which exist in the sensitive papilla of these tentacles, which Ludwig erroneously regards as hollow.

This double connexion of the axial cords of the arms and the cirri with the organs of sense and those of movement confirms the opinion put forward by the English authors. But it must be added that the stellate cells which form the external covering of the cords are themselves in connexion with the cells of connective tissue which fill all the intervals of the calcarcous trabeculæ of the skeleton of the animal, cells which themselves form a continuous network, the last meshes of which are connected with the cells of the epithelium of the arms.

In accordance with the close relationships which exist between all the tissues of the animal, the nervous system consequently remains in a state of remarkable indifferentiation. However it may be, if we assume that the axial cords of the cirri and arms are, as indicated by their anatomical connexions, dependencies of the nervous system, the chambered organ must be considered the central part of that system in the Crinoids ; and these are important conclusions, the morphological consequences of which we shall reserve for future development.

In the parts of the arms in process of formation the tissue of the axial cord does not differ from the three yellow cells which surround it. It is by their free extremities that the arms increase in length. There exists a sort of terminal bud, which soon divides into two at first identical parts : one of these parts grows rapidly, and becomes a pinnule; the other elongates more slowly, and becomes again divided; the half opposite the newly-formed pinnule becomes in its turn a pinnule, and the bud included between the two pinnules continues this mode of division until the growth comes to an end. From this it results that the structure of the arms and that of the pinnules are at first identical. If the pinnule continues its oyolution it becomes a ramification of the arm, and in this way we explain the mode of construction of the multistylate Comatulæ. When the pinnule stops in its evolution it appears to be only a simple appendage; it presents an ambulacral canal, and below this a general cavity, which is usually divided into two very unequal chambers by a transverse partition. This structure is also that of the very young arms, in which the inferior chamber is extremely small. When the genital apparatus is doveloped this structure becomes more complicated. The large chamber of the general cavity is divided afresh into three cavities by the appearance of a horizontal floor and a vertical floor. At the point of junction of these two floors there is a canal occupied in grcat part by the genital rhachis, the ramifications of which in the pinnules become the ovaries or the testes. I have been able to trace all these modifications, and I propose shortly to make them known in all their details.-Comptes Rendus, Juiy 16, 1883 , p. 187. 